\title{
SWOT E- Learning Berbasis Al Quran Pada Masa Pandemi Covid-19
}

\author{
Masripah \\ Universitas Garut \\ Masripah_2@uniga.ac.id
}

\begin{abstract}
Abstrak
Dampak pandemi pada dunia pendidikan mampu mengakselerasi pendidikan Era 4.0 menuju pendidikan Era 5.0. Sistem E-Learning berbasis Al Quran dengan memanfaatkan teknologi informasi yang menarik dan sekaligus menjadi fokus dari penelitian ini bertujuan untuk memperoleh pengetahuan faktual berupa realitas. Sistem pembelajaran dilakukan jarak jauh dengan memanfaatkan teknologi informasi dikenal dengan $E$ Learning berbasis Al Quran sebagai salah satu masalah sekaligus solusi. Penelitian ini menggunakan pendekatan kualitatif dengan metode deskriptif-analisis yang memfokuskan Swot E-Learning Berbasis Al Quran Pada Masa Pandemi Covid 19. Hasil penelitian ini mengindikasikan Pelaksanaan kuliah pembelajaran daring/E-Learning pada masa pandemi ini tentu saja tidak mudah. Berbagai kendala, kekurangan, dan kelebihan sudah tentu ada. Bagi mahasiswa yang mungkin mayoritas sudah melek teknologi, tetapi ternyata masih banyak juga kendala yang sering dirasakan yaitu Pertama, keterbatasan sarana dan prasarana. E-Learning menuntut kecepatan dan kemudahan akses. Kedua, kurangnya pemahaman materi yang disampaikan. Ketiga, tugas yang banyak dan mendadak atau seperti kata mahasiswa, "Tugas kayak tak ada akhlak," itu juga memberatkan mahasiswa, Keempat, kurangnya internalisasi Etika moral dan akhlakul kharimah yang berbasis Qurani. Kelima, Ancamanya adanya oknum yang tidak bertanggung jawab (Hacker) memanipulasi data e-learning. Saran dari jurnal ini adanya komitmen organisasi sebagai prioritas utama baik dalam manajemen, kebijakan maupun kepemimpinan sebagai upaya penyelesaikan masalah Pembelajaran daring dalam rangka menciptakan generasi unggul yang berbasis Al-quran sehingga etika dan akhlakul kharimah dapat tercipta serta adanya sinergitas orangtua, dosen dan mahasiswa.
\end{abstract}

Kata Kunci: Al Quran, E-learning, SWOT

\section{Pendahuluan}

Bencana adanya Pandemi COVID-19 di Indonesia merupakan bagian dari pandemi penyakit coronavirus 2019 (COVID-19) yang sedang berlangsung di seluruh 
dunia. Penyakit ini disebabkan oleh coronavirus sindrom pernapasan akut berat 2 (SARS-cov-2). Kasus positif COVID-19 di Indonesia pertama kali dideteksi pada 2 Maret 2020, ketika dua orang terkonfirmasi tertular dari seorang warga negara Jepang. Pada 9 April, pandemi sudah menyebar ke 34 provinsi dengan Jawa Timur, DKI Jakarta, dan Sulawesi Selatan sebagai provinsi paling terpapar dan sampai sekarangpun masih bertambah walaupun kita telah berupaya dengan protocol kesehatan menuju New Normal. Akan tetapi untuk dunia pendidikan sampai akhir Desember 2020 akan dilakukan dengan E-Learning.

Pandemi Covid-19 berdampak pada dunia pendidikan, termasuk pendidikan tinggi. Adanya wabah virus corona ini menghambat kegiatan belajar mengajar yang biasanya berlangsung secara tatap muka. Kendati begitu, pandemi ini mampu mengakselerasi pendidikan 4.0. Sistem pembelajaran dilakukan jarak jauh dengan memanfaatkan teknologi informasi.

Proses kegiatan belajar mengajar yang semula bisa di ruang-ruang kelas secara tatap muka, kini harus digantikan dengan metode PJJ (Pembelajaran Jarak Jauh) yang memanfaatkan media sosial dan sejumlah aplikasi belajar pada jaman internet. Pembelajaran jarak jauh memang bukanlah hal yang baru dalam dunia pendidikan. Peraturan Menteri Pendidikan dan Kebudayaan Republik Indinesia Nomor 24 Tahun 2012 tentang Penyelenggaraan Pendidikan Jarak Jauh. Sistem PJJ menjadi bagian yang menyatu dalam dunia pendidikan di Indonesia.

Namun kali ini, PJJ dilakukan sebagai bentuk upaya merespons edaran dari Kemdikbud untuk membuat belajar dari rumah lebih fleksibel. Direktorat Jenderal Pendidikan Tinggi (Ditjen Dikti) mengimbau agar perguruan tinggi dengan otonomi yang dimilikinya dapat memberikan fleksibilitas dalam pelaksanaan pembelajaran jarak jauh di masa darurat COVID-19.

Pelaksanaan kuliah daring pada masa pandemi ini tentu saja tidak mudah. Berbagai kendala, kekurangan, dan kelebihan sudah tentu ada. Bagi mahasiswa yang mungkin mayoritas sudah melek teknologi, tetapi ternyata masih banyak juga kendala yang sering dirasakan. Pertama, keterbatasan sarana dan prasarana. Pembelajaran daring menuntut kecepatan dan kemudahan akses. Karena pembelajaran daring akan mudah jika didukung jaringan internet yang kuat dan gawai yang memadai. Tempat tinggal mahasiswa yang berbeda-beda juga menjadi kendala yakni akses sinyal yang sulit. Akses sinyal yang sulit dan kebutuhan paket kuota mengakibatkan mahasiswa menjadi enggan karena akan menghabiskan banyak kuota dan sulit dalam mengikuti proses pembelajaran. Karena harus menyesuaikan juga dengan media yang digunakan dalam pembelajaran yang beragam, mulai menggunakan aplikasi Edmodo, Classroom, Zoom Meeting, Whatsapp, dan sebagainya. Kedua, kurangnya pemahaman materi yang disampaikan. Kuliah daring juga berpengaruh pada pemahaman materi. Sebab kebanyakan mahasiswa atau peserta didik lainnya lebih paham ketika belajar langsung secara tatap muka bukan hanya dengan tatap layar 
gawai. Nyatanya proses pembelajaran belum terpuaskan karena dinilai kurang efektif pada pemahaman materi. Ketiga, tugas yang banyak dan mendadak atau seperti kata mahasiswa, "Tugas kayak tak ada akhlak," itu juga memberatkan mahasiswa. Dosen memberikan beragam tugas menumpuk lalu meminta mahasiswa mengumpulkan tanpa memberikan umpan balik kepada mahasiswa. Jadi perkuliahan hanya berlangsung satu arah bukan kuliah yang dialogis. Keempat, kurangnya internalisasi Etika moral dan akhlakul kharimah yang berbasis Qurani. Kelima Ancamanya adanya oknum yang tidak bertanggung jawab (Hacker) memanipulasi data e-learning.

\section{Metode}

Penelitian ini menggunakan pendekatan kualitatif dengan metode deskriptif analisis yang memfokuskan pada Swot E Learning Berbasis Al Quran Pada Masa Pandemi Covid 19.

\section{Pembahasan}

Penguatan pendidikan karakter yang lazim menjadi sorotan guna membangun karakter peserta didik, bukan semata tanggung jawab sekolah. Melainkan tanggung jawab trisentra pendidikan, yaitu orang tua, sekolah, dan masyarakat. Di tengah penyebaran wabah Covid-19 ini, ketiga peranan tersebut harus dapat menginternalisasikan nilainilai karakter peserta didik dengan bahu-membahu, bersinergi, bergandengan tangan, berkolaborasi, dan bekerja sama agar karakter anak dapat terbangun dengan baik sesuai amanat undang-undang yang dicanangkan oleh pemerintah. Tanpa kerja sama trisentral pendidikan, jangan harap penguatan pendidikan karakter bagi peserta didik akan berhasil dengan baik. Merebaknya wabah Covid-19 ini, pemerintah telah membuat keputusan yang tepat guna memutus rantai wabah tersebut. Yaitu, dengan menganjurkan masyarakat, terutama insan pendidikan untuk stay at home hingga wabah tersebut benar-benar tidak ada dari muka bumi.

Keadaan ini mungkin bisa dimanfaatkan oleh sebagian orang tua agar lebih dekat dengan putra/putrinya. Orang tua lebih bisa menunjukkan kasih sayangnya yang selama ini mereka tinggalkan karena berbagai kesibukan. Orang tua juga jadi merasakan betapa sulitnya mendidik anak sendirian di rumah. Sehingga, membutuhkan pihak lain untuk membantu menginternalisasikan nilai-nilai karakter pada anaknya, yaitu pihak sekolah dan masyarakat.

Namun, menurut saya, dengan stay at home yang begitu lama telah menciptakan kejenuhan bagi semua pihak, di antaranya pihak sekolah yang hanya bisa memantau peserta didik dari kejauhan tanpa tatap muka. Kepala sekolah yang biasa disibukkan dengan berbagai aktivitas, harus mencari alternatif agar kegiatan sekolah tetap berjalan, walau dalam keadaan darurat seperti ini. Kita benar-benar harus memutar otak agar pembelajaran tetap berjalan efektif walau proses KBM dilaksanakan di rumah secara daring.

Proses pembelajaran bukan berarti tanpa kegiatan. Setiap pekan dosen tetap memberikan perkuliahan. Memanfaatkan internet sebagai alat elekronik. Internet 
merupakan suatu media untuk informasi dan berinteraksi kapan dan dimana saja. Melakukan kuliah secara daring (dalam jaringan)/ e-laerning. Dalam berbagai istilah disebut kuliah online; proses pembelajaran ini berlangsung dalam suasana aktif dan dinamis antara dosen dan mahasiswa.

Pola pembelajaran yang semula tatap muka (offline) terpaksa tidak diprioritaskan. Seiring dengan kebijakan kementrian terkait agar pendidikan tinggi sementara masih menggunakan pola pembelajaran secara daring. Sebuah pilihan alternatif di masa pandemi Covid-19. Guna keselamatan dan kesehatan anak bangsa. Pertimbangan lainnya adalah perguruan tinggi dianggap mampu menerapkan pendidikan secara daring. Segenap civitas akademika baik pendidik (dosen), tenaga kependidikan (administrasi/tata usaha) maupun mahasiswa dianggap mumpuni mengimplementasikan teknologi dalam proses pembelajaran.

Menurut Amin, 2020 bahwa Tantangan semakin besar dalam proses pembelajaran daring sebab tujuan pendidikan harus menciptakan generasi unggul bukan mencipatkan generasi Hank apalagi dalam masa pandemi covid 19. Generasi unggul atau tangguh harus memiliki ilmu pengetahuan karena apapun harus dengan ilmu, generasi penerus harus mengusai ilmu pengetahuan, tanpa ilmu bagai tubuh tanpa nyawa. Tanpa ilmu, tidak dapat mengerti tentang arti, sehingga tidak dapat memembeikan manfaat bagi diri dan juga masyarakat. Beribadah membutuhkan ilmu, membangun gedungpun memerlukan ilmu, hingga pergi ke bulan pun membutuhkan ilmu.

Sedangkan menurut Zukifli, 2020 bahwa Pendidikan Islam sangat penting. Perkembangan sangat cepat Era kemajuan teknologi berimbas pada kegiatan sosial, ekonomi, politik, dan pendidikan. Pada 2014 termasuk revolusi industri 0.4 diciptakan di Jerman adalah internet, big data, robotic dan blockchan. Peranan manusia mulai dihilangkan dampaknya akan terjadi Era 5.0. Adanya Pandemi Covid adanya percepatan teknologi Era 4.0 menjadikan pola hidup manusia berubah. Tantangan Bagi Pendidikan Agama Islam adalah:

1. Bagaimana memanusiakan manusia? Karena Teknologi telah mengambil alih pekerjaan manusia

2. Seberapa butuh manusia terhadap agama? Agama formal menjadi usang.

3. Beragaman banyak versi. Islam seperti apa yang diperlu disampaikan ke peserta didik.

Adapun yang perlu dilakukan dalam menghadapi tantangan tersebut :

1. Kuasai Teknologi dan terbuka serta selektif

2. Kembali budaya bangsa dan kembali pada konsep manusia sebagai Khalifah di bumi.

3. Beradaptasi dengan perkembangan pembelajaran menumbuhkan kreatif dan daya inovatif. 
Sedangkan menurut Khusni,2020, bahwa masyarakat sudah dikunci oleh suatu alat atau teknologi pada society 5.0, kemampuan masyarakat pedesaan dan perkotaan sangat berbeda. Karakteristik masyarakat 5.0 adalah

1. Digital Skills artinya masyarakat mempunyai kemampuan memanfaat dunia digital.

2. Problem Solving artinya masyarakat memilki kemampuan pemecahan masalah komplek

3. Creative artinya masyarakat memiliki kreatifitas tinggi

4. Critical Thingking artinya masyarakat memiliki daya pikir yang kritis.

5. Linked Skills artinya masyarakat mampu bergerak dengan bersama, bekerjasam, berjejaring dan berorganisasi.

Kondisi Era Masyarakat 5.0 mempunyai citi bahwa masyakarat tersebut hidupnya penuh gejolak kekaburan informasi, ketidak pastian dan masalah yang komplek. Maka hal ini merupakan tantangan Pendidikan Agama Islam dalam Society 5.0 yang berbasis Al Quran adalah :

1. Minimnya SDM yang mampu mendesain PAI untuk menumbuhkan karakter masyarakat dalam satuan pendidikan

2. Kebijakan pemerintah yang harus meningkatkan SDM tersebut

3. Kebijakan institusi dalam peningkatkan desain pendidikan yang mengarah pada hal tersebut.

4. Kesadaran Masyarakat (orang tua, lingkungan) yang belum maksimal dalam menumbuhkan karakter masyarakat 5.0.

Solusi E-learning berbasis Al Quran harus dimulai dengan antara lain :

1. Ketika berbicara etika dalam kuliah daring dimaksudkan adalah akhlak/nilai/norma yang berlaku ketika proses perkuliahan online. Layaknya kuliah tatap muka, maka diawali dengan salam. Sebagai bagian internalisasi nilai-nilai Islam dalam membangun Islamic Learninng Society selayaknya menanamkan nilai-nilai Islam. Membaca, mentadaburi, mengimplementasikan nilai-nilai Islam dari Al-Qur'an, Hadits maupun ijtihad para fuqoha. Al-Qur'an menyebut komunikasi sebagai salah satu fitrah manusia. Dalam QS. Al-Rahman (55) / 1 - 4)

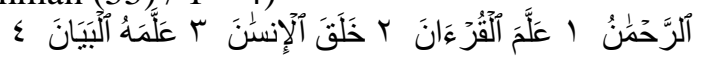

Terjemahnya: (Tuhan) yang Maha pemurah, Yang telah mengajarkan Al-Qur'an. Dia menciptakan manusia. Mengajarnya pandai berbicara".

Al- Quran menampilkan enam prinsip yang seyogyanya dijadikan pegangan dalam berbicara, yaitu:

Pertama Allah menyuruh manusia menyampaikan qaulan sadidan (perkataan benar yakni QS. An Nisa (4) : 9 sebagai berikut

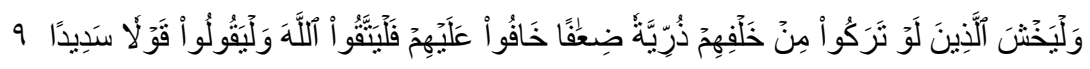

Terjemahnya: Dan hendaklah takut kepada Allah orang-orang yang seandainya meninggalkan dibelakang mereka anak-anak yang lemah, yang mereka khawatir 
terhadap (kesejahteraan) mereka. oleh sebab itu hendaklah mereka bertakwa kepada Allah dan hendaklah mereka mengucapkan Perkataan yang benar.

Kedua, Allah memerintahkan qaulan sesudah takwa, sebagaimana firman Allah dalam QS.Al Ahzab (33) :70

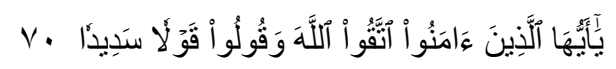

Terjemahnya : Hai orang-orang yang beriman, bertakwalah kamu kepada Allah dan Katakanlah Perkataan yang benar Jadi, Allah swt., memerintahkan manusia untuk senantiasa bertakwa yag dibarengi dengan perkataan yang benar. Nanti Allah akan membalikkan amal-amal kamu, mengampuni dosa kamu. Siapa yang taat kepada Allah dan Rasul-Nya niscaya ia akan mencapai keberuntungan yang besar. Jadi, perkataan yang benar merupakan prinsip komunikasi yang terkandung dalam AlQur'an dan mengandung beberapa makna dari pengertian benar. Diantaranya kata benar yang sesuai dengan kriteria kebenaran. Ucapan yang benar tentu ucapan yang sesuai dengan AlQur'an, Al sunnah, dan ilmu.

Kedua, Qaulana ma'rufa QS An-Nisa (4) :5

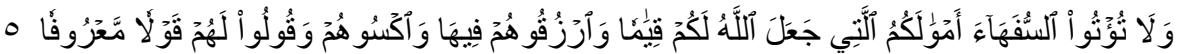

Terjemahannya : Dan janganlah kamu serahkan kepada orang yang belum sempurna akalnya, harta (mereka yang ada dalam kekuasaan) kamu yang dijadikan Allah sebagai pokok kehidupan. Berilah mereka belanja dan pakaian (dari hasil harta itu) dan ucapkanlah kepada mereka perkataan yang baik.

Ketiga, Qaulan Baligha QS An-Nisa (4) : 63

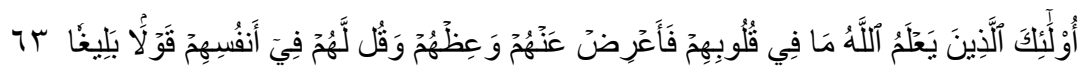

Terjemahnya: Mereka itu adalah orang-orang yang (sesungguhnya) Allah mengetahui apa yang ada di dalam hatinya. Karena itu berpalinglah kamu dari mereka, dan berilah mereka nasihat, dan katakanlah kepada mereka perkataan yang membekas pada jiwanya.

Keempat, Qaulan Massura QS An-Isra (17) : 28

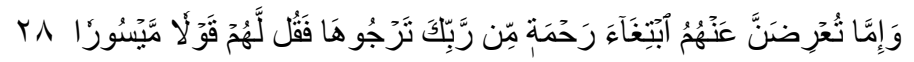

Terjemahnya: Dan jika engkau berpaling dari mereka untuk memperoleh rahmat dari Tuhanmu yang engkau harapkan, maka katakanlah kepada mereka ucapan yang lemah lembut. 
Kelima, Qaulan Layyina QS. Thaha (20) : 44

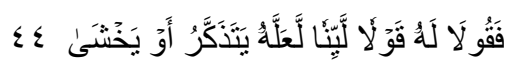

Terjemahnya: maka berbicaralah kamu berdua kepadanya (Fir'aun) dengan kata-kata yang lemah lembut, mudah-mudahan dia sadar atau takut.

Keenam, Qaulan Karima QS. Al Isra (17) : 23

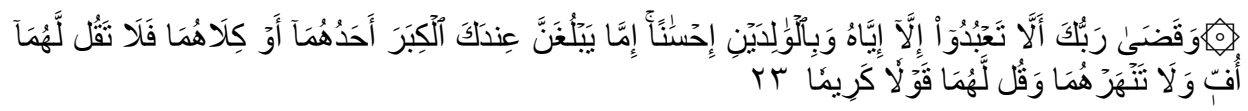

Terjemahnya: Dan Tuhanmu telah memerintahkan agar kamu jangan menyembah selain Dia dan hendaklah berbuat baik kepada ibu bapak. Jika salah seorang di antara keduanya atau kedua-duanya sampai berusia lanjut dalam pemeliharaanmu, maka sekali-kali janganlah engkau mengatakan kepada keduanya perkataan "ah" dan janganlah engkau membentak keduanya, dan ucapkanlah kepada keduanya perkataan yang baik.

2. Ketika proses perkuliahan pun memperhatikan etika dan atau adab selama perkuliahan. Tutur bahasa yang santun dan secara tata busana diharapkan menggunakan pakaian yang sopan dan menutup aurat. Tidak menggunakan kaos oblong, celana pendek dan berposisi layaknya sedang kuliah tatap kuliah. Tidak sambal tidur-tiduran di kasur, misalnya.Terhadap etika dalam berbusana bagi lakilaki, Al-Qur'an mengatur di dalam Surat An-Nur Ayat 30

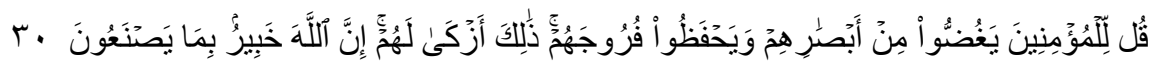

Terjemahnya: Katakanlah kepada laki-laki yang beriman, agar mereka menjaga pandangannya, dan memelihara kemaluannya; yang demikian itu, lebih suci bagi mereka. Sungguh, Allah Maha Mengetahui apa yang mereka perbuat.

Diperlukan internalisasi penguatan pendidikan akhlak, moral, etika dalam proses belajar mengajar walaupun melalui online. Jadi intinya, saat stay at home, penguatan pendidikan karakter harus benar-benar dipraktikkan di rumah dengan pemantauan terus-menerus dari pihak guru/sekolah. Selanjutnya, juga perlu diberikan penguatan pendidikan karakter atau penyadaran terhadap masyarakat dari pihak-pihak terkait tentang pencegahan atau cara memutus rantai penyebaran wabah Covid-19 berskala besar dengan mengikuti anjuran pemerintah.

\section{Kesimpulan}

1) SWOT E-learning berbasi Al Quran dapat dilihat dari 4 sisi adalah

a. Kekuatanya adalah masyarakat yang memiliki fasilitas yang lengkap dapat mengakses pengetahuan yang lebih luas dan melek teknologi. 
b. Kelemahan masyarakat yang tidak memiliki fasilitas yang lengkap dan tidak melek teknologi

c. Ancamannya mahasiswa membuka internet tanpa filter selain itu adanya hacker dari orang yang tidak bertanggung jawab.

d. Peluangnya adalah mahasiswa dapat dengan cepat mengerjakan tugastugas serta mudah mengakses berbagai informasi dan ilmu diseluruh penjuru dunia.

2) Memberikan Suritauladan agar pendidikan karakter dapat tercapai.

3) Kolaborasi Tiga Pilar Pendidikan antara orangtua, pendidikan dan mahasiswa dalam pembelajaran daring terutama aplikasinya.

4) Manusia harus Jujur dan profesional supaya tidak digantikan robot pada masa era.5.0.

5) Metode E-learning berbasis Al Quran adalah Membaca, dihapal, memahami dan

\section{Daftar Pustaka}

Amin.Muhammadiyah, Staf ahli Menteri Agama Bidang Hubungan Kelembagaan Keagamaan, "Tantangan serta penerapan pendidikan untuk mecipatakan mepersiapkan generasi unggul yang mampu bersiang menuju era 5.0STAI Mempawah, Kalimantan Barat, pada 27 Juli 2020 waktu 08.00 wib

Assad Muhammad, 2014, Notes Form Qatar 3, PT elex Media Komputindo, Jakarta

http://dimensipers.com/2020/04/11/polemik-kuliah-daring-di-tengah-pageblukcovid-19/diakses, 27 Juli 2020

http://disdik.jabarprov.go.id/news/2134/internalisasi-penguatan-pendidikankarakter-di-tengah-wabah-covid-19-melalui-pelibatan-orangtua\%2C-sekolah\%2C-dan-masyarakat, diakses 27 Juli 2020

https://suarabaru.id/2020/06/27/etika-kuliah-daring-di-masa-pandemi-covid-19/ diakses 27 Juli 2020

https://ugm.ac.id/id/berita/19552-membedah-tantangan-pembelajaran-daring-ditengah-pandemi-covid-19, diakses 26 Juli 2020

https://www.suara.com/yoursay/2020/04/07/104610/tantangan-dan-peluangpembelajaran-jarak-jauh-bagi-mahasiswa, diakses 26 Juli 2020

Khusni Muhamad, 2020, Penerapan Pendidikan agama Islam menciptakan generasi unggul yang mampu bersiang di Era 5.0, STAI Al Qolam Malang, diakses 27 Juli 2020 jam 10.00 Wib

Masripah, 2019, Ulumul Quran, Universitas Garut, Garut

Muhtadi Saepul Asep,2012, Komunikasi Dakwah,, PT Remaja Rosdakarya, Bandung,

Munir, 2013,Multimedia Konsep \& Aplikasi Pendidikan, Alfabeta Bandung Sauri Sofyan,2006, Pendidikan Berbahasa Santun, PT Genesindo, Bandung Suryana Too dkk,1997 Pendidikan Agama Islam Untuk Perguruan Tinggi, Tiga Mutiara, Bandung 
Zulkifli,2020, Tantangan Pendidikan Agama Islam di Era 4.0 dan menuju 5.0, Dosen IAIN Pontianak, 27 Juli 2020, jam 09.00 Wib 